\title{
THE IMPACT OF HisTORICAL GIN STAND TECHNOLOGIES ON COTTON FIBER AND SEED QUALITY
}

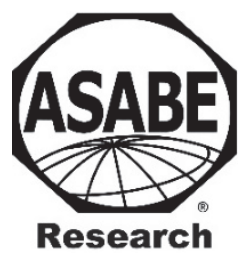

\author{
D. P. Whitelock, M. D. Buser, C. B. Armijo, S. E. Hughs
}

\begin{abstract}
The trend in modern gin stand designs to increase gin stand production rate in terms of bales $/ h$ was generally achieved by increased width, narrower saw spacing, and higher saw loading. This study examined fiber length reductions, short fiber content, fiber neps, and cottonseed damage associated with five saw gin stands of differing production rates, design, and manufacture that represent a range of gin technologies developed since the 1960s to identify technologies from those earlier designs that may guide future gin stand research. Based on rated ginning rate, the gin stands were classified in two general categories, lower capacity (LC, 5 bales/h and less) and higher capacity (HC, 7.5 bales/h and higher). Fiber from the LC gin stands contained fewer fiber neps, longer fibers, less short fiber, and less foreign matter than fiber from the $H C$ gin stands. In addition, cottonseed from the gin stand with lowest capacity had the highest residual linters content and the lowest overall seed damage which aligned with the short fiber content data. Both the LC gin stands were older models and had wider saw spacing; the oldest of them was substantially different from the other designs with two saw mandrels pulling fiber from the same seed roll position. Study results indicate that there may be historical gin stand technologies and relationships between gin parameters such as ginning rate per saw, saw spacing, and seed roll density, and fiber and seed quality that need to be further investigated.
\end{abstract}

Keywords. Cottonseed quality, Cotton ginning, Fiber quality, Gin stand, Length, Neps, Short fiber content, Upland cotton.

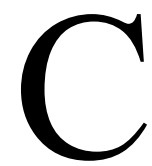

otton short fiber content (SFC) and neps from saw ginning have long been a topic of concern. The percentage of fibers less than $12.7 \mathrm{~mm}$ in length by weight or by number defines SFC (ASTM, 2012a; Uster Technologies, 2015). The SFC in cotton lint is inversely related to yarn strength and can directly affect the quality of a finished product (Anthony, 1985; Krifa et al., 2001). Neps are small knots of tangled fibers, which are created during boll development, harvesting, ginning, and yarn

\footnotetext{
(c) (7) $\Theta$ The authors have paid for open access for this article. This C. ${ }_{\mathrm{BY}} \mathrm{NC}_{\mathrm{ND}}$ work is licensed under a Creative Commons AttributionNonCommercial-NoDerivatives 4.0 International License https://creative commons.org/licenses/by-nc-nd/4.0/

Submitted for review in December 2017 as manuscript number MS 12751; approved for publication as a Research Article by the Machinery Systems Community of ASABE in July 2019.

Mention of trade names or commercial products in this publication is solely for the purpose of providing specific information and does not imply recommendation or endorsement by the U.S. Department of Agriculture. USDA is an equal opportunity providers and employers.

The authors are Derek P. Whitelock, Research Leader, USDA-ARS Southwestern Cotton Ginning Research Laboratory, Mesilla Park, New Mexico; Michael D. Buser, National Program Leader, USDA-ARS Office of National Programs, Beltsville, Maryland; and Carlos B. Armijo, Textile Technologist and S. Ed Hughs, Retired, USDA-ARS Southwestern Cotton Ginning Research Laboratory, Mesilla Park, New Mexico. Corresponding author: Derek P. Whitelock, USDA-ARS Southwestern Cotton Ginning Research Laboratory, PO Box 578, Mesilla Park, NM 88047; phone: 575526-6381; e-mail: derek.whitelock@ars.usda.gov.
} (1) .

.

.

.

.

.


affected by saw spacing, number of teeth per saw, and saw tooth condition. Early saw gin research indicated that seed roll density was a much more significant factor affecting fiber quality than saw speed (Bennett and Gerdes, 1936, 1937). Mangialardi (1985) evaluated nep formation at the gin and determined that gin stands were a major contributor to nepping during gin processing. In another study, ginning rates from 305 to $1,393 \mathrm{~kg}$ (1.4 to 6.4 bales) of lint $/ \mathrm{h}$ did not significantly affect nep count for a gin stand rated at $1,043 \mathrm{~kg}$ ( $4.8 \mathrm{bales})$ of lint/h (Mangialardi et al., 1988). Holt and Laird $(2007,2008,2010)$ conducted more recent studies on their patented powered roll gin stand to increase production and turnout without reducing fiber quality. The main operational components of the technology were the paddle roll that actively turned the seed roll and seed finger roll that presents unginned cottonseed back to the saw. While the powered roll gin stand did show improvements in production rates and fiber quality relative to conventional gin stands, it has not been widely adopted.

Seed damage studies have focused on the effects of pneumatic conveying, gin saw diameter, and ginning rate effects to find methods of reducing seed damage during the ginning process. Anthony (1985) reviewed several studies, which related increased seed damage to increased saw diameter and increased ginning rates. The review stated that seed damage consisting of slits and cracks parallel to the minor axis of the seed have been characterized as conveying damage, while slits and cuts parallel to the major axis of the seed have been defined as damage due to the gin stand. Reducing seed damage is important in terms of increasing germination, as well as improving fiber quality. Seed damage typically results in seed coat fragments (SCF), which can result in additional neps (fiber entangled around a SCF) and higher trash content.

The primary function and basic operating principle of the gin stand has not changed since its invention (Hughs and Holt, 2015). There have been design variations over the years, including huller fronts designed to remove hulls and feed seed cotton into the gin roll box; air or brush doffing systems to remove ginned lint from gin saw; seed tubes to convey seed from inside the seed roll without damage or seed roll agitators to aid in turning the seed roll and improve loading of lint on gin saws to increase capacity; the number of saw mandrels; and the diameter, number, and spacing of gin saws (Mangialardi and Anthony, 2005) (fig. 1). One of the main goals of gin machinery manufacturers over the years has been to increase gin stand capacity (fig. 2). Gin stands manufactured in the late $1950 \mathrm{~s}$ and ' 60 s averaged about 5 bales of lint/h utilizing about 100 saws. On the other hand, gin stands currently advertised have manufacturerrated ginning rates as high as $6,532 \mathrm{~kg}(30 \mathrm{bales}) / \mathrm{h}$ and have more than 200 saws (Hughs et al., 2017). The various improvements mentioned earlier contributed to higher ginning rates, but the main drivers of capacity increases have been narrower saw spacing (11 to $14 \mathrm{~mm}$ ), thus more saws per unit width, and wider gin stands. There is limited information available on how this evolution has affected fiber or seed quality, in particular nep formation and SFC.

The objective of this study was to evaluate gin stands with different configurations that represent levels of gin stand

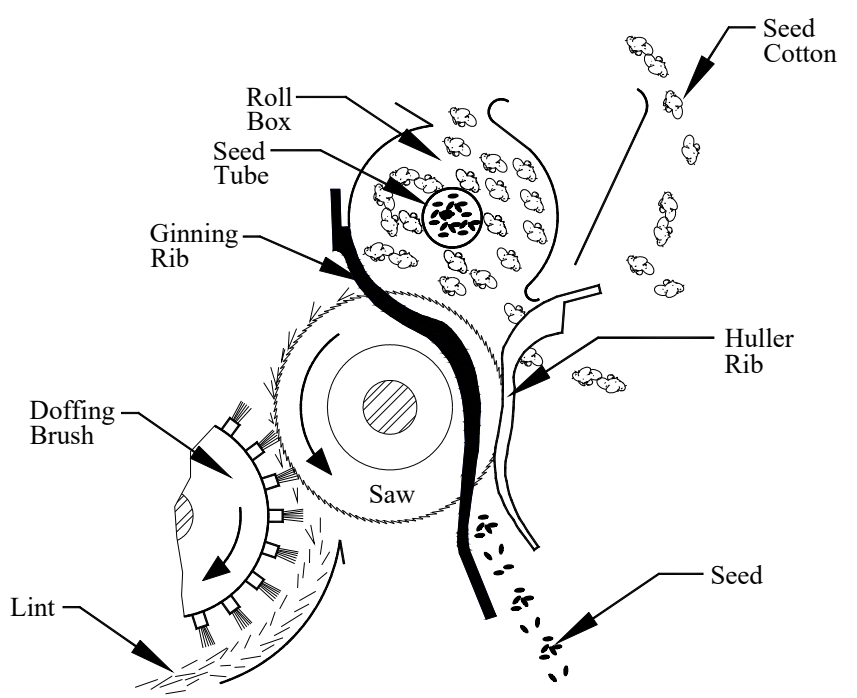

Figure 1. Side view of typical gin stand.

technology developed since the 1960s and determine if the stands produced ginned lint and cottonseed of differing quality, specifically SFC, length, neps, and seed damage. The information obtained from this study could identify old technologies that may have been discontinued during the race for higher capacity, but may be used in future gin stand research to reduce SFC and fiber breakage, neps, and seed damage.

\section{METHODS}

The commercial-size ginning plant at the USDA-ARS Cotton Ginning Research Unit (CGRU) in Stoneville, Mississippi, was used in this study. The recommended seed cotton cleaning sequence for Mid-South spindle-picked cotton was used in this study (Baker et al., 1994). The standard sequence consisted of a 24-shelf tower drier, 6-cylinder incline cleaner, stick machine, 24-shelf tower drier, 6-cylinder inclined cleaner, and extractor-feeder. Five saw-type gin stands of different design in service at the CGRU were evaluated. A comparative list of the details of each gin stand, as supplied by the manufacturer, is shown in table 1 .

The saw gin stands shown from left to right in table 1 represent ginning technologies developed by different manufacturers between the 1960s and 1990s. The gin stands listed in table 1 do not include the newest, widest, highest capacity gin stands that can be obtained from manufacturers today. However, Valco et al. (2018) showed that in 2016 the average rated capacity of gin facilities across the Cotton Belt was about $40 \mathrm{bales} / \mathrm{h}$ and the median total bales ginned was about 30,000 . Because many of the active gin facilities in the United States are lower capacity and gin fewer bales, many of the earlier model gin stands, even from gin manufacturers that have gone out of business or have been merged into other companies, are maintained and remain active in the ginning industry today (Hughs et al., 2017). 


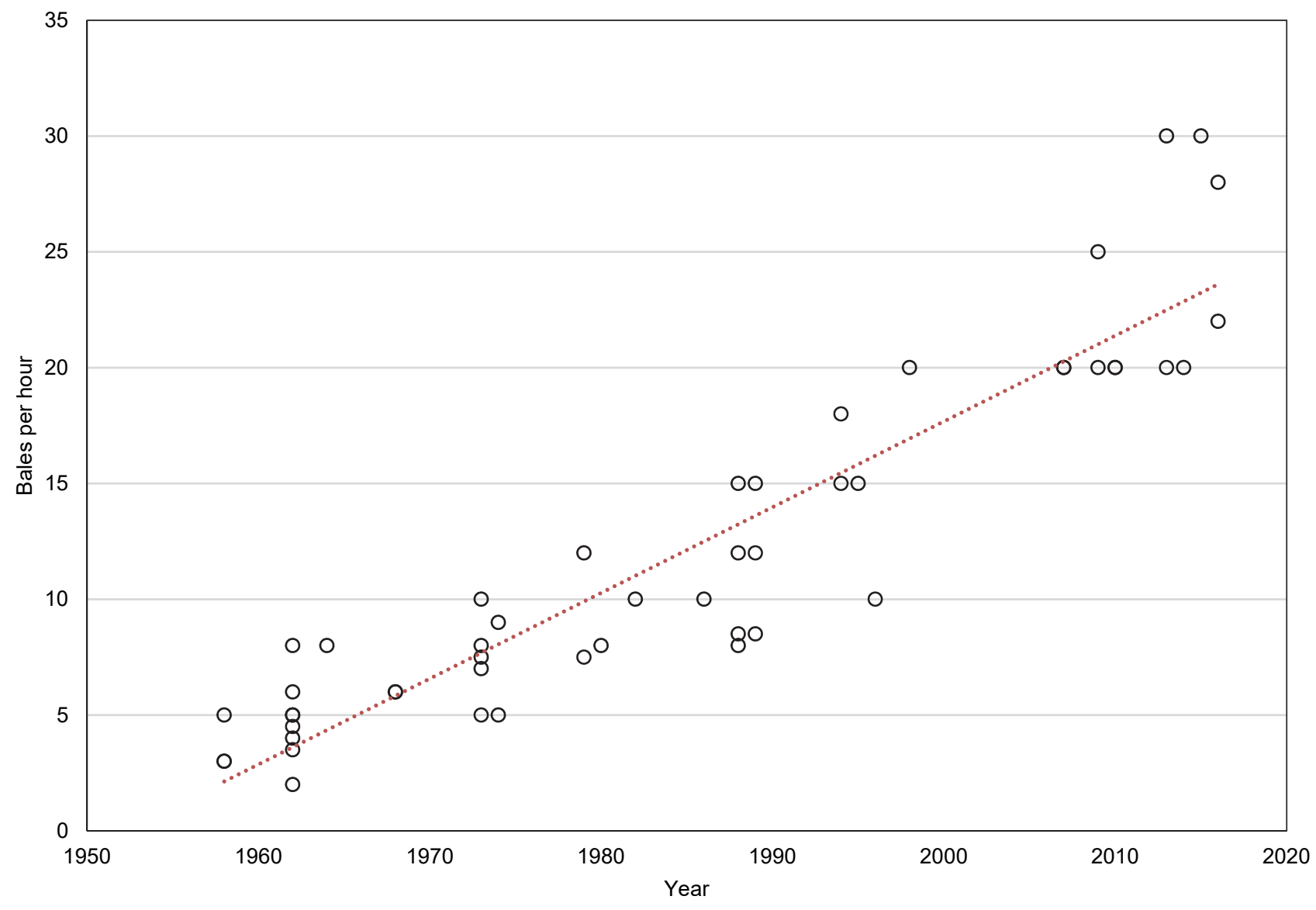

Figure 2. Gin stand rated capacity trend from the 1950s to 2010s (Hughs et al., 2017).

Further information and descriptions of the gin stands in table 1 can be found in Hughs et al. (2017) and Mangialardi and Anthony (2005). Gin stand A was a Hardwicke-Etter Regal 178 (Hardwicke-Etter Company, Sherman, Tex.) that was introduced in 1962 and had 178 total saws spaced $19 \mathrm{~mm}$ apart on dual saw mandrels and rated capacity of $4.5 \mathrm{bales} / \mathrm{h}$. Gin stand A increased capacity over single-man-

Table 1. Gin stand details as specified by the manufacturer (Columbus et al., 1994; Mangialardi and Anthony, 2005; Hughs et al., 2017).

\begin{tabular}{lccccc}
\hline & \multicolumn{5}{c}{ Gin Stand } \\
\cline { 2 - 6 } & $\mathrm{A}^{[\mathrm{a}]}$ & $\mathrm{B}^{[\mathrm{a}]}$ & $\mathrm{C}^{[\mathrm{b}]}$ & $\mathrm{D}^{[\mathrm{b}]}$ & $\mathrm{E}^{[\mathrm{b}]}$ \\
\hline Saw spacing, mm & 19.0 & 15.9 & 15.9 & 12.7 & 12.7 \\
Saw diameter, mm & 298,305 & 406 & 406 & 305 & 305 \\
Saw speed, rpm & 695,650 & 625 & 615 & 841 & 850 \\
No. of saws & 178 & 93 & 93 & 112 & 116 \\
$\quad$ No. of saw cylinders & 2 & 1 & 1 & 1 & 1 \\
$\begin{array}{l}\text { Roll box width, m } \\
\text { Recommended ginning rate, }\end{array}$ & 1.73 & 1.60 & 1.60 & 1.65 & 1.68 \\
$\quad$ bales/h & & 5 & 7.5 & 8.5 & 10 \\
$\quad$ Recommended saw loading, & $4.9-5.5$ & 11.7 & 17.6 & 16.6 & 18.8 \\
$\quad$ kg/saw/h & No & No & Seed & Agitator Agitator \\
Seed roll modification & & \multicolumn{5}{c}{ tube } \\
$\quad$ Motor power, $\mathrm{kW}$ & 37 & 37 & 56 & 56 & 75 \\
\hline
\end{tabular}

[a] Lower-capacity (LC) saw-type gin stand.

[b] Higher-capacity (HC) saw-type gin stand. drel gin stands of the time by positioning an upper saw mandrel above and parallel with the lower mandrel to pull fiber from the same seed roll, thus plucking lint from unginned cotton in the seed roll where single saws did not. With the addition of the second saw mandrel, processing rate per saw was more on the order of earlier gin stands. The dual saw principle utilized more saws in the gin stand, but was designed to take up the same floor space as a 90 -saw gin stand. Gin stand B was a 93-saw Continental Eagle (Continental Eagle Corporation, Prattville) from model year 1973 (Hughs et al., 2017). Gin stand B had similar capacity and power requirement as gin stand $\mathrm{A}$, but used a single saw mandrel with larger 406-mm diameter saws spaced approximately $3 \mathrm{~mm}$ closer together. Gin stand C was a 1979 Continental 93-saw Double Eagle (Continental Eagle Corporation, Prattville, Ala.) and represented a higher capacity gin than gin stand B. This was accomplished through increased motor power and the addition of a seed tube in the center of the seed roll box that allowed a higher rate of seed discharge from the seed roll. Gin stand D was a Consolidated Horn 112 (Consolidated HGM Corporation, Lubbock, Tex.) from 1989. This stand had rated capacity one bale/h greater than gin stand $\mathrm{C}$ at the same power requirement. This was achieved mainly through more (112) and narrower spaced $(12.7 \mathrm{~mm})$ saws. Also, gin stand D had a powered agitator 
cylinder in the roll box to aid rotation of the seed roll. Gin stand E was the newest model gin stand, a 1996 model year Lummus 116-saw Imperial III (Lummus Corporation, Savannah, Ga.). This gin stand, though narrower and with fewer saws than the very newest models offered by many manufacturers today, is still advertised by the manufacturer and represents modern gin stand technology featuring 12.7-mm saw spacing, hullerless front, and seed roll agitator. For the purpose of this study, the manufacturer of the individual machines is unimportant thus, the gin stands will simply be referred to as gin stands A-E from this point forward.

The gin stands in table 1 represent a range of gin technologies with similar widths, but different number of saws and capacities. Broadly speaking, they represent engineering to increase ginning efficiency by increasing gin stand production rate in terms of bales/hour/stand. There are a number of design differences between the gin stands but, with the exception of gin stand A, increased production was accomplished by decreasing gin saw spacing (putting more saws pulling fiber in the same space in the roll box) and increasing seed roll density to increase saw tooth loading. There were also differences between saw diameters and speeds, but the actual tip velocity of the saw teeth between the different gin stands was not greatly different. Gin stand A's saw tip speed was approximately $10.7 \mathrm{~m} / \mathrm{s}$ for its two saws while the tip speeds of the other four gin stands ranged from 13.2 to
$13.6 \mathrm{~m} / \mathrm{s}$. Referring to table 1, the five saw gin stands represent a broad span of saw gin production that follows the general trend of gin design since 1960 and can be expressed as individual saw loading in $\mathrm{kg} / \mathrm{saw} / \mathrm{h}$ (fig. 3). Evaluating the test ginning rates in terms of saw loading rates allows a more direct comparison of all five gins.

The target ginning rate for each gin stand was the manufacturer's recommended ginning rate. Gin stands A and B had lower recommended ginning rates (4.5-5 bales/h), lower capacity (LC), and gin stands C, D, and E had higher recommended ginning rates $(7.5-10$ bales/h), higher capacity $(\mathrm{HC})$. However, due to differences in cotton cultivar and moisture content, some deviation from the target rates was expected. Prior to conducting the test, all five gin stands were inspected to determine the operational ginning rates, if the saws were dull and/or damaged, and shaft speeds. Necessary adjustments were made to bring the stands to the manufacturer's specifications. As part of these preliminary adjustments, approximately two bales of cotton $(1,361 \mathrm{~kg}$ of seed cotton) were processed on each gin stand to evaluate their respective ginning rates. Gin stands A, B, and C processed the seed cotton slightly faster than the manufacturers' recommended rates, while stands D and E were approximately $10 \%$ below the manufacturers' recommended rates. The load on the gin stand motor can range up to about $110 \%$ before it is disengaged. The feed rate for gin stands $\mathrm{D}$ and $\mathrm{E}$ were set at approximately $60 \%$ to $70 \%$ of the full-capacity setting.

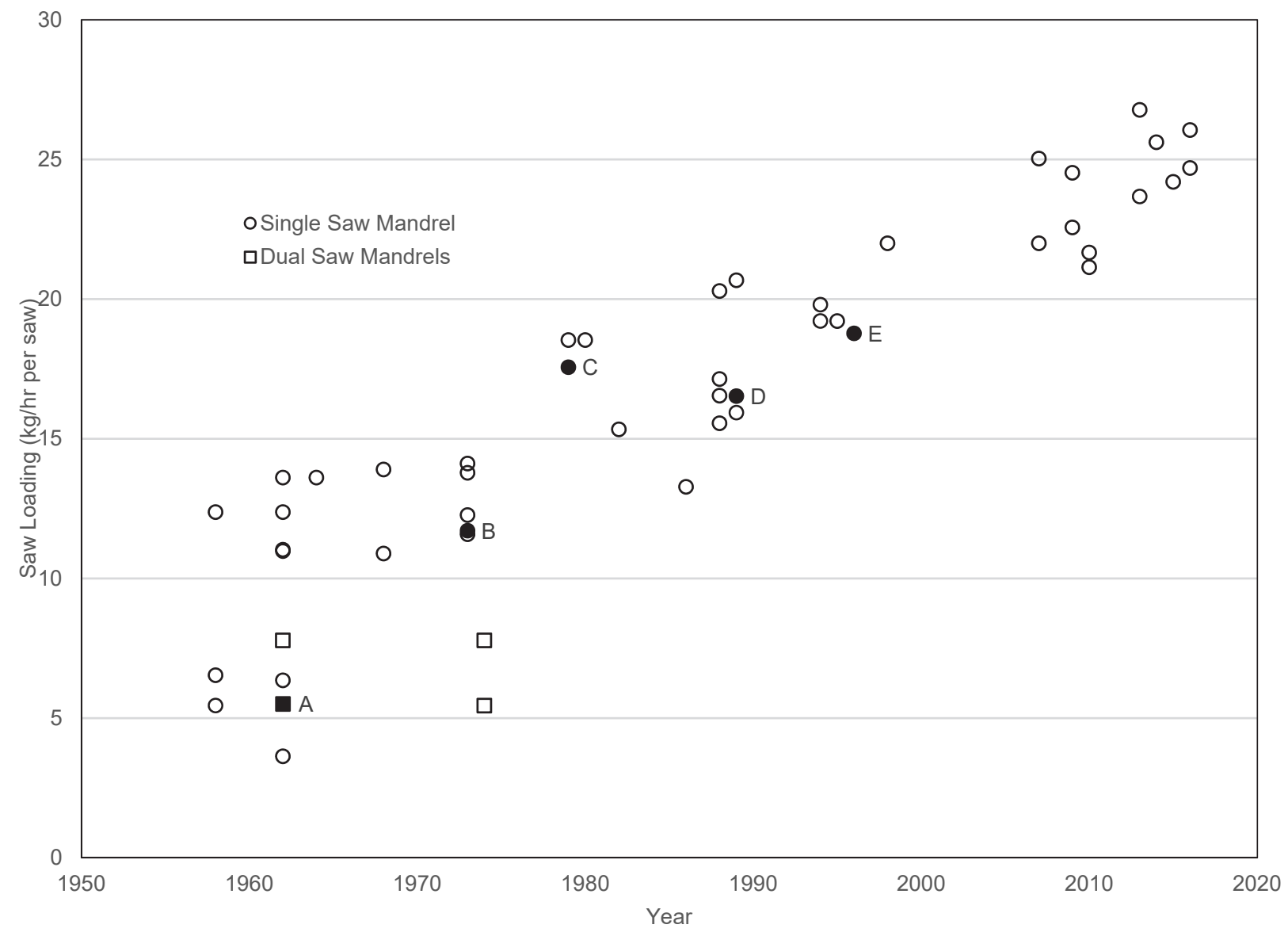

Figure 3. Gin stand saw loading trends from the 1950s to 2010s (Hughs et al., 2017). Darkened data markers with letters represent gin stands listed in table 1. 
However, when either of these gin stands was pushed beyond these limits, their gin breasts disengaged, ceasing operation. The gin stand specifications were re-checked, the recommended rates were confirmed by the manufacturer, and although the ginning rates on gin stands $\mathrm{D}$ and $\mathrm{E}$ deviated from the manufacturer's recommended rate, the study was completed while maintaining the highest achievable ginning rate for the stands.

This study was conducted over two ginning seasons. The first ginning season test (Test 1) consisted of three replications, two cotton cultivars, and five gin stands for a total of 30 lots. Each lot consisted of $227 \mathrm{~kg}$ of seed cotton. By comparison, a 218-kg standard bale of cotton lint requires about $682 \mathrm{~kg}$ of seed cotton. The cotton cultivars used in Test 1 were Suregrow 125 and 501 (Delta and Pine Land Company, now part of Bayer Crop Science, Research Triangle Park, N.C.). The seed cotton was grown, spindle-harvested, and moduled near Leland, Mississippi.

Lot numbers were assigned to the Test 1 gin stand treatments in a randomized arrangement and blocked by cultivar, due to the difficulty of handling modules after the covers were removed and the module was partially ginned. To ensure that each gin stand was operating at normal steady-state conditions, approximately $227 \mathrm{~kg}$ of seed cotton was ginned prior to each lot, thus increasing the total number of bales required for Test 1 to 20. Furthermore, sample collection was performed after the gin stands reached the desired processing rate and before the rate declined to ensure that samples were collected at the target rates. Dryer temperature for Test 1 was $82^{\circ} \mathrm{C}$ at the top of the first dryer, while no heat was used in the second tower dryer.

For each lot, five lint samples were collected after the gin stands to determine fiber properties by the Advanced Fiber Information System (AFIS, Uster Technologies, Knoxville, Tenn.). Five lint samples were collected to determine fiber properties by the High Volume Instrument (HVI, Uster Technologies, Knoxville, Tenn.) at a USDA-AMS classing office. The unprocessed portion of the HVI samples (about $200 \mathrm{~g}$ ) were returned from the classing office. These samples were then processed on the Shirley Analyzer to determine trash content (ASTM, 2012b). Three additional lint samples were used for moisture content determination by the ovendrying method (Shepherd, 1972). SCF, mote, and funiculi analysis and lint seed-content measurement were performed on another lint sample collected after the gin stand (ASTM, 1980). One cottonseed sample was used for residual linter measurements and five additional cottonseed samples were used for seed damage classification according to CGRU procedures summarized below.

The second ginning season test (Test 2) consisted of three replications, one cultivar, and five gin stands for a total of 15 lots. Each lot consisted of $682 \mathrm{~kg}$ of seed cotton. The cotton cultivar used in Test 2 was Stoneville 747 (Stoneville Cotton, now part of Bayer Crop Science, Research Triangle Park, N.C.). The seed cotton was grown, spindle-harvested, and moduled by the KLB Farms Partners in Leland, Mississippi.

Lot numbers were assigned to the Test 2 gin stand treatments in a randomized arrangement. Similar to Test 1, approximately $227 \mathrm{~kg}$ of seed cotton was ginned prior to each lot. Sample collection was performed after the gin stands reached the desired rate and before the capacity declined. For Test 2, the dryer temperature was $65^{\circ} \mathrm{C}$ at the top of the first dryer and again, no heat was used in the second tower dryer.

Similar to Test 1, five lint samples were collected after the gin stands for AFIS measurements, five were collected for HVI measurements, three were collected for moisture content determination, and one was collected for SCF, mote, and funiculi analyses. Lint seed-content was not measured on Test 2 samples. Instead of using HVI samples returned from the classing office, five additional lint samples were collected for processing on the Shirley Analyzer to determine trash content. Three cottonseed samples collected from the seed-belt were used for residual linter measurements and five cottonseed samples were used for seed damage classification.

AFIS measurements for Test 1 were performed by Cotton Incorporated (Cary, N.C.). The HVI sample measurements for Tests 1 and 2 were completed by the USDA-AMS Cotton Classing Office in Dumas, Arkansas. Mid Continent Laboratory (Memphis, Tenn.) performed the linters measurements on the cottonseed samples from both tests. The Fiber Testing Laboratory at the CGRU completed the following measurements for this study: AFIS on lint samples from Test 2, and Shirley Analyzer lint trash measurements, lint SCF contents, moisture content determination, and seed damage classification on Tests 1 and 2.

Seed damage classification was conducted according to CGRU Fiber Testing Laboratory standard procedures. For the procedure, 200 fuzzy cottonseeds were collected from a cottonseed sample and acid delinted. After delinting, 100 seeds were randomly selected for visual mechanical damage inspection. Each seed was inspected and classified as either normal or abnormal. Abnormal cottonseeds were classified into three categories: 1) shriveled - small and usually curled; 2) Immature - full size seed, light in color, not fully developed inside and may have thin seed coats; or 3) damaged - shriveled and immature seed can also be damaged. In this procedure, the damage to the cottonseed can be further classified as pinhole damage - seeds with only one or two small (pinhole) punctures in seed coats; minor damage - seeds with seed coats cracked or cut, but not severely; or major damage - seeds with large cuts or ruptures in the seed coats, part of the seed coats missing, or damage to the radicle end of the seeds. For the types of damage, the number of cuts, the number of cuts parallel to the minor axis, the number of cuts parallel to the major axis, and the number of cracks on the seed can be determined.

Statistical data analyses were performed on the data from each test separately using the Mixed procedure in SAS (version 7, SAS Institute, Inc., Cary, N.C.) with a $5 \%$ level of significance used to identify differences. For Test 1 , cultivar, gin stand, and their interaction were the main effects with replication*cultivar*gin stand as the random effect. For Test 2 , only gin stand was the main effect with replication*gin stand as the random effect. Multiple comparison procedures were conducted on the means using the default LSD t-test $(\mathrm{p} \leq 0.05)$. 


\section{RESULTS}

The saw loading and ginning rates achieved during testing are shown in table 2. During Test 1 of this study, gin stands A and B produced ginning rates that were higher than the manufacturers' recommended ginning rates. The ginning rates achieved by gin stands D and E were $24 \%$ and $35 \%$ lower than the recommended ginning rates, respectively, based on average rates across both cultivars. For Test 2, ginning rates achieved for gin stands A and B were slightly higher than the recommended rates, while gin stands D and E were $29 \%$ and $32 \%$ lower, respectively, than the manufacturer's recommended ginning rate.

The average seed cotton moisture content prior to ginning in Test 1 was $6.7 \%$ and $6.5 \%$ for Suregrow 125 and Suregrow 501, respectively. After ginning in Test 1, the lint moisture content averaged 3.9\%. During Test 2 with Stoneville 747 , the average seed cotton moisture content was $5.5 \%$ prior to ginning and lint moisture content was 3.7\% after ginning. There were no significant differences in the before ginning seed cotton moisture content or after ginning lint moisture content among the five gin stand treatments for either Tests 1 or 2.

The gin stand $\times$ cultivar interaction was not found significant in the statistical analyses of the data from Test 1 . Thus, fiber and cottonseed quality results for Test 1 are presented as averages across the two cultivars and statistical analyses consider only the gin stand main effect.

\section{AFIS Fiber Properties}

AFIS fiber properties for each gin stand treatment are shown in table 3 for Test 1 with the Suregrow 125 and Suregrow 501 cultivars and for Test 2 with the Stoneville 747 cultivar. In Test 1 , gin stand A produced lint with the smaller-sized neps than the other four gin stands. Nep size was not different among gin stands in Test 2 . It is important to note that nep size has little practical importance, while nep count has more influence on textile utility. Gin stand B produced lint with the fewest number of neps (209) among the stands in Test 1. Gin stand A had the next lowest average nep count (246), but was not significantly different than gin stands D and E. Average nep count was lowest in fiber produced by gin stand A for the Stoneville cultivar in Test 2, but this was only significantly different from stand D. In general, the LC gin stands (A and B) produced fewer and smaller neps than the $\mathrm{HC}$ gin stands $(\mathrm{C}, \mathrm{D}$, and $\mathrm{E})$, but these differences were not always significantly different.

For both tests, fiber length by weight, $\mathrm{L}(\mathrm{w})$, and number, $\mathrm{L}(\mathrm{n})$, were different among gin stands and tended to be
Table 3. Tests 1 and 2 AFIS measurement means for gin stand treatments.

\begin{tabular}{|c|c|c|c|c|c|}
\hline \multirow[b]{2}{*}{$\underline{\text { Measurement }}{ }^{[\mathrm{b}]}$} & \multicolumn{5}{|c|}{ Gin Stand $^{[\mathrm{a}]}$} \\
\hline & $\mathrm{A}^{[\mathrm{c}]}$ & $\mathrm{B}^{[\mathrm{c}]}$ & $\mathrm{C}^{[\mathrm{d}]}$ & $\mathrm{D}^{[\mathrm{d}]}$ & $\mathrm{E}^{[\mathrm{d}]}$ \\
\hline \multicolumn{6}{|l|}{ Test 1} \\
\hline Nep Size $[\mu \mathrm{m}]$ & $744 \mathrm{a}$ & $765 \mathrm{c}$ & $752 \mathrm{~b}$ & $753 \mathrm{~b}$ & $763 \mathrm{c}$ \\
\hline Neps [count/g] & $246 \mathrm{~b}$ & $209 a$ & $283 \mathrm{c}$ & $278 \mathrm{bc}$ & $264 \mathrm{bc}$ \\
\hline $\mathrm{L}(\mathrm{w})[\mathrm{mm}]$ & $26.1 \mathrm{~d}$ & $25.9 \mathrm{~cd}$ & $24.9 \mathrm{a}$ & $25.4 \mathrm{ab}$ & $25.5 \mathrm{bc}$ \\
\hline $\mathrm{L}(\mathrm{w}) \mathrm{CV}[\%]$ & 30.5 a & $31.4 \mathrm{ab}$ & $32.8 \mathrm{~b}$ & $32.0 \mathrm{ab}$ & $32.0 \mathrm{ab}$ \\
\hline $\mathrm{UQL}(\mathrm{w})[\mathrm{mm}]$ & $30.8 \mathrm{c}$ & $30.8 \mathrm{c}$ & $30.1 \mathrm{a}$ & $30.3 \mathrm{ab}$ & $30.5 \mathrm{~b}$ \\
\hline $\mathrm{SFC}(\mathrm{w})[\%]$ & $5.6 \mathrm{a}$ & $6.3 \mathrm{a}$ & $7.7 \mathrm{~b}$ & $6.8 \mathrm{ab}$ & $6.8 \mathrm{ab}$ \\
\hline $\mathrm{L}(\mathrm{n})[\mathrm{mm}]$ & $22.5 \mathrm{c}$ & $22.1 \mathrm{bc}$ & $21.0 \mathrm{a}$ & $21.6 \mathrm{ab}$ & $21.7 \mathrm{abc}$ \\
\hline $\mathrm{L}(\mathrm{n}) \mathrm{CV}[\%]$ & 39.9 a & $41.2 \mathrm{ab}$ & $43.3 \mathrm{~b}$ & $41.7 \mathrm{ab}$ & $41.7 \mathrm{ab}$ \\
\hline $\mathrm{SFC}(\mathrm{n})[\%]$ & 16.0 a & $17.6 \mathrm{ab}$ & $20.7 \mathrm{~b}$ & $18.4 \mathrm{ab}$ & $18.5 \mathrm{ab}$ \\
\hline $\mathrm{L} 5 \%(\mathrm{n})[\mathrm{mm}]$ & 34.9 c & $34.9 \mathrm{c}$ & $34.2 \mathrm{a}$ & $34.5 \mathrm{ab}$ & $34.6 \mathrm{bc}$ \\
\hline $\mathrm{L} 2.5 \%(\mathrm{n})[\mathrm{mm}]$ & $37.3 \mathrm{~d}$ & $37.3 \mathrm{~cd}$ & $36.4 \mathrm{a}$ & $36.8 \mathrm{~b}$ & $36.9 \mathrm{bc}$ \\
\hline Total $[$ count/g] & 164 a & $540 \mathrm{c}$ & $224 \mathrm{~b}$ & $169 \mathrm{c}$ & $235 \mathrm{~b}$ \\
\hline Trash Size $[\mu \mathrm{m}]$ & $399 \mathrm{ab}$ & $379 a$ & $425 \mathrm{~cd}$ & $436 d$ & $406 \mathrm{bc}$ \\
\hline Dust [count/g] & $128 \mathrm{a}$ & $435 \mathrm{c}$ & $174 \mathrm{~b}$ & $130 \mathrm{a}$ & $185 \mathrm{~b}$ \\
\hline Trash [count/g] & 36 a & $106 \mathrm{c}$ & $50 \mathrm{~b}$ & $39 a$ & $50 \mathrm{~b}$ \\
\hline VFM [\%] & 0.8 a & $2.6 \mathrm{~d}$ & $1.3 \mathrm{c}$ & $1.0 \mathrm{~b}$ & $1.2 \mathrm{bc}$ \\
\hline SCN Size $[\mu \mathrm{m}]$ & $1014 \mathrm{ab}$ & 1003 a & $1048 \mathrm{~b}$ & $1017 \mathrm{ab}$ & $1019 \mathrm{ab}$ \\
\hline $\mathrm{SCN}$ [count/g] & $13.1 \mathrm{a}$ & $24.5 \mathrm{~b}$ & $16.6 \mathrm{a}$ & $20.2 \mathrm{a}$ & $25.4 \mathrm{~b}$ \\
\hline Fineness [mTex] & 172 a & $173 \mathrm{ab}$ & $172 \mathrm{ab}$ & $172 \mathrm{ab}$ & $173 \mathrm{~b}$ \\
\hline $\operatorname{IFC}[\%]$ & 5.7 & 5.6 & 5.8 & 5.9 & 5.7 \\
\hline Maturity Ratio & 0.940 & 0.940 & 0.926 & 0.929 & 0.937 \\
\hline \multicolumn{6}{|l|}{ Test 2} \\
\hline Nep Size $[\mu \mathrm{m}]$ & 711 & 727 & 715 & 719 & 717 \\
\hline Neps per gram & $150 \mathrm{a}$ & $159 \mathrm{a}$ & $156 \mathrm{a}$ & $174 \mathrm{~b}$ & $158 \mathrm{a}$ \\
\hline $\mathrm{L}(\mathrm{w})[\mathrm{mm}]$ & $25.7 \mathrm{~d}$ & $25.5 \mathrm{~cd}$ & $25.2 \mathrm{ab}$ & $25.0 \mathrm{a}$ & $25.3 \mathrm{bc}$ \\
\hline $\mathrm{L}(\mathrm{w}) \mathrm{CV}[\%]$ & 30.3 a & $31.5 \mathrm{~b}$ & $31.9 \mathrm{~b}$ & $32.5 \mathrm{c}$ & $31.8 \mathrm{~b}$ \\
\hline $\mathrm{UQL}(\mathrm{w})[\mathrm{mm}]$ & 30.5 & 30.5 & 30.3 & 30.3 & 30.4 \\
\hline $\mathrm{SFC}(\mathrm{w})[\%]$ & $6.27 \mathrm{a}$ & $7.13 \mathrm{~b}$ & $7.75 \mathrm{~cd}$ & $8.13 \mathrm{~d}$ & $7.47 \mathrm{bc}$ \\
\hline $\mathrm{L}(\mathrm{n})[\mathrm{mm}]$ & $21.5 \mathrm{~d}$ & $21.1 \mathrm{c}$ & $20.6 \mathrm{ab}$ & $20.3 \mathrm{a}$ & $20.8 \mathrm{~b}$ \\
\hline $\mathrm{L}(\mathrm{n}) \mathrm{CV}[\%]$ & $44.1 \mathrm{a}$ & $46.0 \mathrm{~b}$ & $47.0 \mathrm{c}$ & $48.0 \mathrm{~d}$ & $46.8 \mathrm{bc}$ \\
\hline $\mathrm{SFC}(\mathrm{n})[\%]$ & 20.0 a & $22.1 \mathrm{~b}$ & $23.5 \mathrm{c}$ & $24.5 \mathrm{~d}$ & $23.0 \mathrm{bc}$ \\
\hline $\mathrm{L} 5 \%(\mathrm{n})[\mathrm{mm}]$ & 34.0 & 34.1 & 33.7 & 33.8 & 34.0 \\
\hline $\mathrm{L} 2.5 \%(\mathrm{n})[\mathrm{mm}]$ & 35.9 & 36.0 & 35.6 & 35.7 & 35.9 \\
\hline Total [count/gram] & 304 a & $391 \mathrm{~b}$ & $384 \mathrm{ab}$ & $499 \mathrm{c}$ & $367 \mathrm{ab}$ \\
\hline Trash Size $[\mu \mathrm{m}]$ & 318 & 309 & 305 & 311 & 303 \\
\hline Dust [count/gram] & $257 \mathbf{a}$ & $337 \mathrm{a}$ & $333 \mathrm{a}$ & $427 \mathrm{~b}$ & $318 \mathrm{a}$ \\
\hline Trash [count/gram] & 47.4 a & $54.6 \mathrm{a}$ & $50.7 \mathrm{a}$ & $72.5 \mathrm{~b}$ & $48.3 \mathrm{a}$ \\
\hline VFM [\%] & $1.00 \mathrm{a}$ & $1.13 \mathrm{a}$ & $1.10 \mathrm{a}$ & $1.49 \mathrm{~b}$ & $1.14 \mathrm{a}$ \\
\hline SCN Size $[\mu \mathrm{m}]$ & 1151 & 1060 & 1143 & 1102 & 1122 \\
\hline SCN per gram & $15.9 \mathrm{ab}$ & $23.2 \mathrm{c}$ & $14.3 \mathrm{a}$ & $22.7 \mathrm{c}$ & $18.2 \mathrm{~b}$ \\
\hline Fineness [mTex] & $185 \mathrm{~b}$ & $181 \mathrm{a}$ & $182 \mathrm{a}$ & 180 a & $182 \mathrm{a}$ \\
\hline $\operatorname{IFC}[\%]$ & $4.84 \mathrm{a}$ & $5.43 \mathrm{~b}$ & $5.25 \mathrm{~b}$ & $5.55 \mathrm{~b}$ & $5.28 \mathrm{~b}$ \\
\hline Maturity Ratio & 0.92 b & $0.90 \mathrm{a}$ & $0.91 \mathrm{ab}$ & $0.90 \mathrm{a}$ & $0.91 \mathrm{ab}$ \\
\hline
\end{tabular}

[a] Means followed by different lower-case letters in each row are significantly different at the 0.05 level. Bold numbers in each row are more desirable.

[b] Descriptions of measurements are shown in the Appendix.

[c] Lower-capacity (LC) saw-type gin stand.

[d] Higher-capacity (HC) saw-type gin stand.

Table 2. Manufacturers recommended and actual saw loading and ginning rates for each cultivar in Test 1 and Test 2.

\begin{tabular}{|c|c|c|c|c|c|}
\hline \multirow{3}{*}{$\begin{array}{c}\text { Gin } \\
\text { Stand }\end{array}$} & \multirow{3}{*}{$\begin{array}{c}\text { Recommended } \\
\text { Saw Loading (ginning rate) } \\
\mathrm{kg} / \mathrm{saw} / \mathrm{h}(\text { bales } / \mathrm{h})\end{array}$} & \multicolumn{4}{|c|}{ Actual Saw Loading (ginning rate), $\mathrm{kg} / \mathrm{saw} / \mathrm{h}$ (bales $/ \mathrm{h}$ ) } \\
\hline & & \multicolumn{3}{|c|}{ Test $1^{[\mathrm{c}]}$} & \multirow{2}{*}{$\begin{array}{c}\text { Test } 2^{[\mathrm{c}]} \\
\text { Stoneville } 747\end{array}$} \\
\hline & & Suregrow 125 & Suregrow 501 & Mean & \\
\hline $\mathrm{A}^{[\mathrm{a}]}$ & $4.9-5.5(4.0$ to 4.5$)$ & $6.1(5.0) \mathrm{a}$ & $5.6(4.6) \mathrm{a}$ & $5.9(4.8) \mathrm{a}$ & $5.8(4.7)$ \\
\hline $\mathrm{B}^{[\mathrm{a}]}$ & $11.7(5.0)$ & $14.8(6.3) \mathrm{b}$ & $12.9(5.5) \mathrm{b}$ & $13.8(5.9) \mathrm{b}$ & $12.4(5.3)$ \\
\hline $\mathrm{C}^{[\mathrm{b}]}$ & $17.6(7.5)$ & $19.5(8.3) \mathrm{d}$ & $16.0(6.8) \mathrm{c}$ & $17.6(7.5) \mathrm{d}$ & $16.7(7.1)$ \\
\hline $\mathrm{D}^{[\mathrm{b}]}$ & $16.6(8.5)$ & $14.2(7.3) \mathrm{c}$ & $11.1(5.7) b$ & $12.7(6.5) \mathrm{c}$ & $11.7(6.0)$ \\
\hline $\mathrm{E}^{[\mathrm{b}]}$ & $18.8(10.0)$ & $13.7(7.3) \mathrm{c}$ & $10.9(5.8) \mathrm{b}$ & $12.2(6.5) \mathrm{c}$ & $12.8(6.8)$ \\
\hline
\end{tabular}

[a] Lower-capacity (LC) saw-type gin stand.

[b] Higher-capacity (HC) saw-type gin stand.

[c] Means in Test 1 followed by different lower-case letters in each column are significantly different at the 0.05 level. Not available in Test 2 . 
longer for cotton ginned on gin stands $\mathrm{A}$ and $\mathrm{B}$. $\mathrm{L}(\mathrm{w})$ on gin stand A averaged $26.1 \mathrm{~mm}$ for Test 1 with Suregrow 125 and Suregrow 501 cultivars and $25.7 \mathrm{~mm}$ for Test 2 with Stoneville 747 cultivar. In both tests, average $\mathrm{L}(\mathrm{w})$ on gin stand $\mathrm{B}$ was longer than the HC stands, but not significantly different from gin stand E. L(n) averaged about $22.3 \mathrm{~mm}$ for stands A and $\mathrm{B}$ in Test 1 . This was not significantly different from $\mathrm{L}(\mathrm{n})$ for stand $\mathrm{E}(21.7 \mathrm{~mm})$. Both the LC gins stands produced lint in Test 2 with average $L(n)$ values (21.5 and $21.1 \mathrm{~mm}$ for $\mathrm{A}$ and $\mathrm{B}$, respectively) that were significantly longer than that from the $\mathrm{HC}$ gin stands.

AFIS upper quartile length by weight, UQL(w), and upper $5 \%$ and $2.5 \%$ length by number, L5\%(n) and L2.5\%(n), had similar trends to $\mathrm{L}(\mathrm{w})$ and $\mathrm{L}(\mathrm{n})$, but there were no significant differences in these measures among gin stands in Test 2. UQL(w) was different among gin stands with the Suregrow cultivars in Test 1 with gin stands A and B producing fiber with significantly better UQL(w) $(30.8 \mathrm{~mm})$ than gin stands C, D, or E (ranged from 30.1 to $30.5 \mathrm{~mm}$ ). Also in Test 1, gin stands A and B both had L2.5\%(n) and L5\%(n) averages of 37.3 and $34.9 \mathrm{~mm}$, respectively, that were significantly better than the values for $\mathrm{HC}$ gin stands $\mathrm{C}$ and D. With the single cultivar in Test 2, UQL(w) averaged $30.4 \mathrm{~mm}, \mathrm{~L} 5 \%(\mathrm{n})$ averaged $33.9 \mathrm{~mm}$, and L2.5\%(n) averaged $35.9 \mathrm{~mm}$. As stated above, none of these were different among the gin stands. Based on the overall AFIS length information, the lower ginning rate gin stands (LC stands A and $\mathrm{B}$ ) on average produced longer fiber than the high ginning rate gin stands ( $\mathrm{HC}$ stand $\mathrm{C}, \mathrm{D}$, and $\mathrm{E}$ ) but, as with the nep measurements, these differences were often not significantly different.

In both tests, there were significant differences in short fiber content by weight and number, SFC(w) and SFC(n), and coefficient of variation of fiber length by weight and number, $\mathrm{L}(\mathrm{w}) \mathrm{CV}$ and $\mathrm{L}(\mathrm{n}) \mathrm{CV}$, among gin stands. With the Suregrow cultivars, average $\mathrm{SFC}(\mathrm{w})$ and $\mathrm{SFC}(\mathrm{n})$ in Test 1 were lowest for gin stand $\mathrm{A}(5.63 \%$ and $16.0 \%)$, but these were only significantly different from stand $\mathrm{C}$ that had the highest values. On the other hand, in Test 2, average SFC(w) and SFC(n) from gin stand A (6.27 and 20.0\%) were significantly better than all other stands and stand D had the highest average values with the Stoneville cultivar in Test 2. There were practically no differences in $\mathrm{L}(\mathrm{w}) \mathrm{CV}$ and $\mathrm{L}(\mathrm{n}) \mathrm{CV}$ among gin stands in Test 1 , with only gin stand A having values significantly different from gin stand $\mathrm{C}$. In Test 2, gin stand $\mathrm{A}$ had length $\mathrm{CV}$ values that were lowest $(\mathrm{L}(\mathrm{w}) \mathrm{CV}=30.3 \%$ and $\mathrm{L}(\mathrm{n}) \mathrm{CV}=44.1 \%)$ and significantly different from all other gin stands. Trends in these data show that LC gin stands (A and B) generally produced less short fiber and fiber with less length variability than the $\mathrm{HC}$ gin stands (D, C, and E), but there was too much variability in the data to conclude that many of the differences were significant.

Total count, trash count, dust count, and visible foreign matter (VFM) average values were lowest in fiber produced by gin stand $\mathrm{A}$ in both tests, but only total count and VFM in Test 1 for stand A were significantly different from all other stands. Total count per gram ranged from 164 (gin stand A) to 540 (gin stand B) in Test 1 with the Suregrow cultivars and 304 (gin stand A) to 499 (gin stand D) in Test 2 with the Stoneville 747 cultivar. VFM ranged from 0.8 (gin stand A) to $2.6 \%$ (gin stand B) in Test 1 and from 1.00 (gin stand A) to $1.49 \%$ (gin stand D) in Test 2.

There were no definitive differences in seed coat nep ( $\mathrm{SCN}$ ) size and $\mathrm{SCN}$ count between the $\mathrm{LC}$ and $\mathrm{HC}$ gin stands. SCN count in Test 1 ranged from 13.1 to 25.4 particles/g, with gin stand A having the lowest count and gin stand E having the highest count. SCN count in Test 2 was lowest for gin stand C (14.3 particles/g) and significantly different from the highest level of 23.2 particles/g for gin stand B. SCN size in Test 1 ranged from 1003 to $1048 \mu \mathrm{m}$ for stands $\mathrm{B}$ and $\mathrm{C}$, which were significantly different, but there was no difference among the other gin stands. No differences in $\mathrm{SCN}$ size were detected among any of the gin stands in Test 2.

There were few differences in fineness, immature fiber content (IFC), and maturity ratio among gin stands. Fineness averaged 173 mTex, IFC averaged 5.72, and maturity ratio averaged 0.93 for the Suregrow cultivars. With respect to the Stoneville cultivar, fineness averaged $182 \mathrm{mTex}$, IFC averaged 5.3, and maturity ratio averaged 0.91 . In Test 2 , fiber from gin stand A was significantly more mature, but less fine - although the values for all gin stands were "average" maturity and fineness. Fineness, immature fiber content, and maturity ratio are more dependent on the inherent properties of the cotton than on the gin stand treatment used, therefore the significant differences in these measurements are likely less a function of gin stand treatment and more a function of the cotton prior to ginning.

\section{HVI FibER Properties}

HVI fiber properties for each gin stand treatment for Test 1 with the Suregrow 125 and Suregrow 501 cultivars and for Test 2 with the Stoneville 747 cultivar are shown in table 4 . With the exception of reflectance, trash area, and length, none of the HVI fiber properties were significantly different among gin stands in Test 1 . In Test 1 , micronaire, strength, yellowness, and length uniformity averaged 45.3, $31.5 \mathrm{~g} / \mathrm{tex}, 8.93+\mathrm{b}$, and $83.8 \%$, respectively. Gin stand A produced fiber with the best color reflectance (74.9 Rd), which was significantly different from all the other gin stands, but may also be attributed to lower trash levels. The longest fiber was also from gin stand A $(29.1 \mathrm{~mm})$, but it was only significantly different from gin stand D. Trash area was lowest for stand $\mathrm{E}$ at $3.80 \%$, but this was not significantly different from either of the LC stands. There were no conclusive differences in the HVI measurements between the LC and $\mathrm{HC}$ gin stands in Test 2. Micronaire was not different among the gin stands and averaged 4.71. Fiber strength averaged $29.4 \mathrm{~g} /$ tex, was highest for fiber from gin stands B and $\mathrm{E}$ at $29.7 \mathrm{~g} /$ tex, and gin stands $\mathrm{A}$ and $\mathrm{C}$ had the lowest at $29.2 \mathrm{~g} / \mathrm{tex}$. Gin stands normally do not affect fiber strength, so differences noted may have been mostly due to small natural variation in the cotton. Reflectance ranged from 76.9 (gin stand D) to $78.5 \mathrm{Rd}$ (gin stand $\mathrm{A}$ ) and yellowness ranged from 9.0 (gin stand C) to $9.23+\mathrm{b}$ (gin stand B). Length was also not different among gin stands and averaged $29.0 \mathrm{~mm}$. Although length uniformity was different among gin stands, it only ranged from 84.3 (gin stands C and D) to 84.8 (gin stand A). 
Table 4. Test 1 and Test 2 HVI measurement means gin stand treatments.

\begin{tabular}{|c|c|c|c|c|c|}
\hline \multirow{2}{*}{$\underline{\text { Measurement }}{ }^{[\mathrm{b}]}$} & \multicolumn{5}{|c|}{ Gin Stand ${ }^{[\mathrm{a}]}$} \\
\hline & $\mathrm{A}^{[\mathrm{c}]}$ & $\mathrm{B}^{[\mathrm{c}]}$ & $\mathrm{C}^{[\mathrm{d}]}$ & $\mathrm{D}^{[\mathrm{d}]}$ & $\mathrm{E}^{[\mathrm{d}]}$ \\
\hline \multicolumn{6}{|l|}{ Test 1} \\
\hline Micronaire [reading] & 4.53 & 4.56 & 4.51 & 4.55 & 4.51 \\
\hline Strength $[\mathrm{g} / \mathrm{tex}]$ & 31.8 & 31.3 & 31.5 & 31.4 & 31.4 \\
\hline Reflectance [Rd] & $74.9 \mathrm{~b}$ & $73.8 \mathrm{a}$ & $74.1 \mathrm{a}$ & $73.8 \mathrm{a}$ & $74.0 \mathrm{a}$ \\
\hline Yellowness $[+\mathrm{b}]$ & 8.84 & 8.92 & 8.92 & 9.01 & 8.97 \\
\hline Trash Area [\%] & $4.00 \mathrm{ab}$ & $3.93 \mathrm{a}$ & $4.63 \mathrm{c}$ & $4.53 \mathrm{bc}$ & 3.80 a \\
\hline Length $[\mathrm{mm}]$ & $29.1 \mathrm{~b}$ & $28.9 \mathrm{ab}$ & $28.9 \mathrm{ab}$ & $28.8 \mathrm{a}$ & $29.0 \mathrm{ab}$ \\
\hline Length Uniformity [\%] & 83.6 & 83.8 & 83.8 & 83.7 & 83.8 \\
\hline \multicolumn{6}{|l|}{ Test 2} \\
\hline Micronaire [rea & 4.73 & 4.71 & 4.71 & 4.73 & 4.69 \\
\hline Strength $[\mathrm{g} / \mathrm{tex}]$ & $29.2 \mathrm{a}$ & $29.7 \mathrm{~b}$ & $29.2 \mathrm{a}$ & $29.5 \mathrm{ab}$ & $29.7 \mathrm{~b}$ \\
\hline Reflectance [Rd] & $78.5 \mathrm{~b}$ & $77.2 \mathrm{ab}$ & $77.9 \mathrm{ab}$ & $76.9 \mathrm{a}$ & $78.0 \mathrm{ab}$ \\
\hline $\mathrm{s}[+\mathrm{b}]$ & $9.05 \mathrm{a}$ & $9.23 \mathrm{~b}$ & $9.00 \mathrm{a}$ & $9.07 \mathrm{ab}$ & $9.02 \mathrm{a}$ \\
\hline Trash Area [\%] & $2.27 \mathrm{a}$ & $2.40 \mathrm{ab}$ & $2.73 \mathrm{ab}$ & $3.13 \mathrm{~b}$ & $2.60 \mathrm{ab}$ \\
\hline Length $[\mathrm{mm}]$ & 29.0 & 29.2 & 29.0 & 29.0 & 29.0 \\
\hline Length Uniformity [\%] & 84.8 b & $84.5 \mathrm{ab}$ & $84.3 \mathrm{a}$ & $84.3 \mathrm{a}$ & $84.4 \mathrm{ab}$ \\
\hline \multicolumn{6}{|c|}{$\begin{array}{l}\text { Means followed by different lower-case letters in each row are signifi- } \\
\text { cantly different at the } 0.05 \text { level. Bold numbers in each row are more } \\
\text { desirable. }\end{array}$} \\
\hline \multicolumn{6}{|c|}{ [b] Descriptions of measurements are shown in the Appendix. } \\
\hline \multicolumn{6}{|c|}{$\begin{array}{l}\text { [c] Lower-capacity (LC) saw-type gin stand. } \\
\text { [d] Hioher-canacity }\end{array}$} \\
\hline Higher-capa & & & & & \\
\hline
\end{tabular}

All micronaire readings were in the base range (4.3-4.9) and strength readings were in the premium range ( $\geq 27.5 \mathrm{~g} /$ tex) according to the CCC Loan Premium and Discount Schedule. Fiber length uniformity for all cultivars was in the "high" category (83\%-85\%) according to the classing office definition. Color grades associated with the average reflectance and yellowness values using an HVI color diagram for American Upland Cotton were 31 for gin stands A, $\mathrm{D}$, and $\mathrm{E}$ and 41 for gin stands $\mathrm{B}$ and $\mathrm{C}$ in Test 1 and 21 for gin stands $\mathrm{A}, \mathrm{B}, \mathrm{C}$, and $\mathrm{E}$ and 31 for gin stand $\mathrm{D}$ in Test 2.

\section{Lint Foreign Matter Properties}

There were differences in Shirley Analyzer visible trash among individual gin stands, but there were no clear differences between the LC and $\mathrm{HC}$ stands (table 5). Visible trash ranged from 3.35 to 4.19 in Test 1 . Gin stand A had the lowest value and was only significantly different from the highest value for gin stand D. In Test 2, gin stand D again had the highest average visible trash $(3.23 \%)$, which was different from that of all other gin stands.

\section{Seed Coat Fragment, Mote, Funiculi Analysis, AND LINT SEED-CONTENT}

SCF, mote, and funiculi analysis and lint seed-content results for Tests 1 and 2 are shown in table 6. SCF properties had similar results as HVI and foreign matter properties above, in that there were no clear differences between the

Table 5. Test 1 and Test 2 Shirley visible trash means for gin stand treatments.

\begin{tabular}{llllll}
\hline & & \multicolumn{5}{c}{ Gin Stand ${ }^{[\mathrm{a}]}$} \\
\cline { 2 - 6 } & $\mathrm{A}^{[\mathrm{c}]}$ & $\mathrm{B}^{[\mathrm{c}]}$ & $\mathrm{C}^{[\mathrm{d}]}$ & $\mathrm{D}^{[\mathrm{d}]}$ & $\mathrm{E}^{[\mathrm{d}]}$ \\
\hline Test 1 visible trash [\%] & $\mathbf{3 . 3 5} \mathbf{~ a}$ & $3.54 \mathrm{ab}$ & $3.63 \mathrm{ab}$ & $4.19 \mathrm{~b}$ & $3.52 \mathrm{a}$ \\
Test 2 visible trash [\%] & $\mathbf{2 . 1 2} \mathbf{~ a}$ & $\mathbf{2 . 1 2} \mathbf{~ a}$ & $2.17 \mathrm{a}$ & $3.23 \mathrm{~b}$ & $2.18 \mathrm{a}$ \\
\hline [a] & Means followed by different lower-case letters in each row are signifi- \\
& cantly different at the 0.05 level. Bold numbers in each row are more \\
desirable. & \\
[b] & Descriptions of measurements are shown in the Appendix. \\
[c] & Lower-capacity (LC) saw-type gin stand. \\
[d] & Higher-capacity (HC) saw-type gin stand.
\end{tabular}

Table 6. Test 1 and Test 2 SCF, mote, and funiculi analysis and lint seed-content measurement means for gin stand treatments.

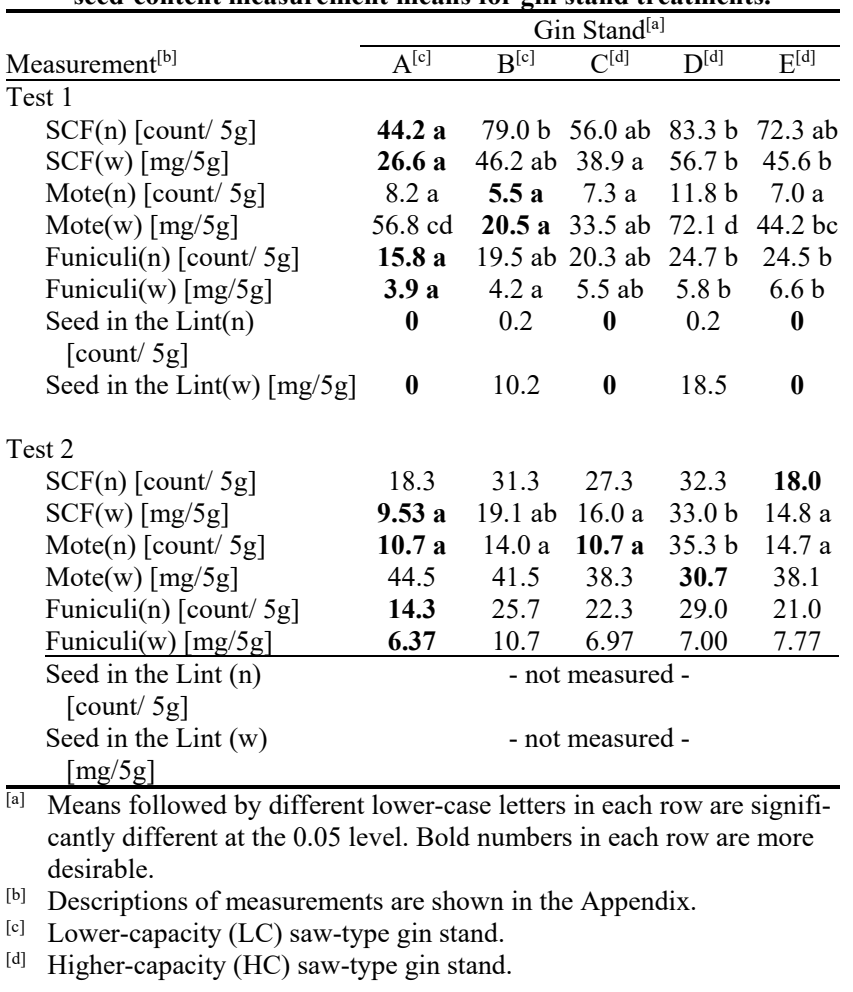

LC and $\mathrm{HC}$ gin stands. In Test 1 , gin stands A and B tended to have the lower average SCF property values but, in all cases, they were not significantly different from the values for several of the other gin stands. Gin stand A, which had the lowest ginning rate, had the fewest SCF by number, $\mathrm{SCF}(\mathrm{n})$, and was only different from gin stands B and D. $\mathrm{SCF}(\mathrm{n})$ ranged from 44.2 per $5 \mathrm{~g}$ of lint (gin stand A) to 83.3 per $5 \mathrm{~g}$ (gin stand $\mathrm{D}$ ). In Test 2 , there were no significant difference in $\operatorname{SCF}(n)$ among gin stands and it ranged from 18 per $5 \mathrm{~g}$ of lint (gin stand $\mathrm{E}$ ) to 32.3 per $5 \mathrm{~g}$ (gin stand $\mathrm{D}$ ). In both tests, gin stand $\mathrm{D}$ consistently produced lint with the largest count of fiber motes by number (11.8 and 35.3 per $5 \mathrm{~g}$ of lint for Tests 1 and 2, respectively), Mote(n), and that was significantly different from all the other gin stand averages. Fiber funiculi produced by gin stand A in Test 1 was lowest in number (15.8 particles per $5 \mathrm{~g}$ of lint) and weight (3.9 $\mathrm{mg}$ per $5 \mathrm{~g}$ sample of fiber). These numbers were significantly different than the same measurements for gin stands D and E, but not B and C. Fiber funiculi was not different among gin stands in Test 2 with the Stoneville 747 cultivar and averaged 22.5 particles and $7.76 \mathrm{mg}$ per $5 \mathrm{~g}$. Based on this information, the LC gins (which had the lowest ginning rate) generally produced fiber with the least amount of SCF, but the differences were not always statistically significant. There was no difference among gin stands in the amount of seed found in the lint from Test 1 , where seed count averaged 0.1 and seed weight average $5.7 \mathrm{mg}$.

\section{CotTonsed Properties}

Cottonseed properties for Tests 1 and 2 are shown in table 7. Seed damage was different among gin stands in both tests. Gin stand A had the lowest level of seed damage (3.1\% and $2.0 \%$ in Tests 1 and 2, respectively). Interestingly, gin 
Table 7. Tests 1 and 2 cottonseed property means for gin stand treatments.

\begin{tabular}{|c|c|c|c|c|c|}
\hline \multirow{2}{*}{ Measurement ${ }^{[\mathrm{b}]}$} & \multicolumn{5}{|c|}{ Gin Stand $^{[\mathrm{a}]}$} \\
\hline & $\mathrm{A}^{[\mathrm{c}]}$ & $\mathrm{B}^{[\mathrm{c}]}$ & $\mathrm{C}^{[\mathrm{d}]}$ & $\mathrm{D}^{[\mathrm{d}]}$ & $\mathrm{E}^{[\mathrm{d}]}$ \\
\hline \multicolumn{6}{|l|}{ Test 1} \\
\hline Seed Damage (\%) & $3.1 \mathrm{a}$ & $8.0 \mathrm{c}$ & $5.6 \mathrm{~b}$ & $5.4 \mathrm{~b}$ & $8.3 \mathrm{c}$ \\
\hline Linters $(\%)$ & $13.7 \mathrm{c}$ & $12.3 \mathrm{ab}$ & $12.8 \mathrm{~b}$ & $12.4 \mathrm{ab}$ & 11.9 a \\
\hline \multicolumn{6}{|l|}{ Test 2} \\
\hline Seed Damage (\%) & $2.00 \mathrm{a}$ & $4.44 \mathrm{~b}$ & $3.22 \mathrm{ab}$ & $3.44 \mathrm{ab}$ & $4.22 \mathrm{~b}$ \\
\hline Linters $(\%)$ & 7.87 & 7.83 & 7.90 & 8.03 & 7.87 \\
\hline \multicolumn{6}{|c|}{$\begin{array}{l}\text { Means followed by different lower-case letters in each row are signifi- } \\
\text { cantly different at the } 0.05 \text { level. Bold numbers in each row are more } \\
\text { desirable. }\end{array}$} \\
\hline \multicolumn{6}{|c|}{ b] Descriptions of measurements are shown in the Appendix. } \\
\hline \multicolumn{6}{|c|}{ [c] Lower-capacity (LC) saw-type gin stand. } \\
\hline \multicolumn{6}{|c|}{ [d] Higher-capacity (HC) saw-type gin stand. } \\
\hline
\end{tabular}

stand $\mathrm{B}$, the other low ginning rate gin stand with wider saw spacing had the largest amount of seed damage (Test $1=$ $8.0 \%$ and Test $2=4.4 \%$ ) and was not significantly different from gin stand $\mathrm{E}$ in Test 1 and not different from any of the $\mathrm{HC}$ gin stands in Test 2.

Linters content was different among gin stands with the Suregrow cultivars. Linters content ranged from $11.9 \%$ to $13.7 \%$, was lowest for seed from gin stand E, and highest and significantly different from the other gin stands for gin stand A. Linters content was not different among gin stands with the Stoneville cultivar and averaged $7.9 \%$.

\section{DISCUSSION}

Overall, these results revealed some general and consistent trends for the gin stands. Ginning rates for the LC gin stands A and B were slightly higher than the manufacturers recommended ginning rates, but considerably lower than the $\mathrm{HC}$ gins stands. Gin stands D and E operated at about $30 \%$ below the manufacturers recommended ginning rates possibly due to cotton cultivar characteristics (ginning rates were within $10 \%$ of the manufacturer's recommended ginning rate in a preliminary test with a different cultivar), or software calibration issues with the electronic feed control. Gin stand $\mathrm{C}$ with the highest actual saw loading and ginning rate for both tests operated nearly at the recommended rate during tests. The study was completed with the highest achievable ginning rates with the given cultivars. Though many of the differences in fiber and seed properties were not significantly different at the 5\% significance level, there were obvious trends in the data when comparing $\mathrm{LC}$ and $\mathrm{HC}$ stands. As indicated by the bolded values in the tables, the LC stands, particularly stand A, had the more desirable average values for the majority of the fiber and cottonseed measurements in Tests 1 and 2. Conversely, the HC stands C and D had the majority of the least desirable fiber and seed measurement values in both tests. These trends may be related back to gin stand design characteristics shown in table 1. For example, gin stand A had two saw mandrels, wide saw spacing and roll box width and the lowest saw loading, while gin stands $\mathrm{C}$ and $\mathrm{D}$ had narrower saw spacing and higher saw loading. As the trend in modern gin stand designs is toward narrower saw spacing and higher saw loading, the influence of gin saw spacing, diameter, speed, and loading, and seed roll density on fiber and seed quality warrant further controlled testing.

\section{CONCLUSIONS}

Tests were conducted on five different gin stands that represent a range of historical gin technologies with different widths, number of saws, and capacities to identify technologies from those earlier designs that may guide future gin stand research to improve fiber quality. Two of the stands had rated capacity lower than 5 bales/h (LC gin stands) and three had rated capacity of 7.5 bales/h or higher (HC gin stands). Seed cotton moisture content prior to ginning and lint moisture content after ginning were not different among gin stands. In general, the LC gin stands with lower ginning rate had wider saw spacing and lower saw loading $(\mathrm{kg} / \mathrm{saw} / \mathrm{h})$ than the $\mathrm{HC}$ gin stands. These LC gin stands produced fewer neps, longer fiber, and less SFC in cotton ginned than the $\mathrm{HC}$ gin stands. The LC gin stand with lowest saw loading routinely produced fiber with less trash in the lint than the other gin stands. Fineness, immature fiber content, and maturity ratio were more dependent on cotton cultivar than on the gin stand treatment used. The AFIS measurements favored the LC stands and so did the HVI measurements, but to a lesser extent. The lowest ginning rate gin stand had higher residual linters content and lower seed damage than the other stands, which aligns with the short fiber content results.

In summary, although the differences in fiber and seed properties between the LC and HC gin stands were not always statistically significant at the $5 \%$ significance level, the fiber properties associated with the $\mathrm{LC}$ gin stands tended to be superior to the fiber properties associated with the $\mathrm{HC}$ gin stands. Both the LC gin stands were older models and had wider saw spacing; the oldest of them was substantially different from the other designs with two saw mandrels pulling fiber from the same seed roll position. These results indicate that there may be historical gin stand technologies and relationships between gin parameters such as saw loading, saw spacing, and seed roll density, and fiber and seed quality that need to be further investigated.

\section{ACKNOWLEDGEMENTS}

The authors wish to express thanks to the KLB Farms Partners, Leland, Mississippi, USDA-ARS Application and Production Technology Unit, and the Mississippi Agricultural and Forestry Extension Service for supplying the cotton used in the project, Burdette Gin Company for providing the module transportation, and Cotton Incorporated for providing AFIS measurements.

\section{REFERENCES}

Anthony, W. S. (1985). The effect of gin stands on cotton fiber and seed. Cotton Gin Oil Mill Press, 86(16), 14-18.

ASTM. (1980). D2496-80: Test method for seed coat fragments and funiculi in cotton fiber samples (withdrawn 1986). West Conshohocken, PA: ASTM Int. 
ASTM. (2012a). D1440-7: Standard test method for length and length distribution of cotton fibers (array method). West Conshohocken, PA: ASTM Int.

ASTM. (2012b). D2812-7: Standard test method for non-lint content of cotton. West Conshohocken, PA: ASTM Int.

Baker, R. V., Anthony, W. S., \& Sutton, R. M. (1994). Seed cotton cleaning and extracting. In Cotton ginners handbook (pp. 6990). Washington, DC: USDA.

Bennett, C. A., \& Gerdes, F. L. (1936). Effects of gin-saw speed and seed-roll density on quality of cotton lint and operation of gin stands (Vol. 501). Washington, DC: USDA.

Bennett, C. A., \& Gerdes, F. L. (1937). Effects of feeds and saw speeds on cotton turn-out and quality. Washington, DC: USDA.

Columbus, E. P., van Doom, D. W., Norman, B. M., \& Sutton, R. M. (1994). Gin stands. In Cotton ginners handbook (pp. 90102). Washington, DC: USDA.

Griffin Jr., A. C. (1979). High-capacity ginning and fiber breakage. Textile Res. J., 49(3), 123-126. https://doi.org/10.1177/004051757904900301

Holt, G., \& Laird, W. (2007). Screening for optimal operating parameters for the powered roll gin stand using Taguchi's robust design. J. Cotton Sci., 11(1), 79-90.

Holt, G. A., \& Laird, J. W. (2008). Initial fiber quality comparisons of the power roll gin stand to three different makes of conventional gin stands. Appl. Eng. Agric., 24(3), 295-299. https://doi.org/10.13031/2013.24498

Holt, G. A., \& Laird, J. W. (2010). Power roll gin stand technology: Evaluation and optimization of rib rail angle and ginning point modifications on a retrofitted lummus gin stand. Appl. Eng. Agric., 26(2), 209-215. https://doi.org/10.13031/2013.29539

Hughs, E., \& Holt, G. (2015). Ginning. In D. D. Fang, \& R. G. Percy (Eds.), Cotton (2nd. ed., pp. 609-664). Madison, WI: ASA, CSSA, SSSA. https://doi.org/10.2134/agronmonogr57.2013.0048
Hughs, E., Holt, G., \& Rutherford, R. (2017). Saw gin stands. J. Cotton Sci., 21(1), 60-69.

Krifa, M., Gourlot, J. P., \& Drean J., Y. (2001). Effect of seed coat fragments on cotton yam strength: Dependence on fiber quality. Text Res. J., 71(11), 981-986. https://doi.org/10.1177/004051750107101108

Mangialardi Jr., G. J. (1985). Neps in ginned lint: A review of research. Proc. Beltwide Cotton Production Research Conf. (pp. 358-362). Memphis, TN: National Cotton Council.

Mangialardi Jr., G. J., \& Anthony, W. S. (2005). Cotton gin saw developments. Memphis, TN: National Cotton Ginners Assoc.

Mangialardi Jr., G. J., Bargeron III, J. D., \& Rayburn Jr., S. T. (1988). Gin-stand feed rate effects on cotton quality. Trans. ASAE, 31(6), 1844-1850. https://doi.org/10.13031/2013.30945

Shepherd, J. V. (1972). Standard procedures for foreign matter and moisture analytical tests used in cotton ginning research. Washington, DC: USDA.

Uster Technologies. (2015). Uster AFIS Pro 2. Retrieved from https://www.uster.com/fileadmin/customer/Instruments/Fiber_T esting/AVIS_Pro/en_USTER_AFIS_PRO_2_TD_2015_11.pdf

Valco, T. D., Ashley, H., Findley, D. S., Green, J. K., Isom, R. A., \& Price, T. L. (2018). The cost of ginning cotton-2016 survey results. Proc. Beltwide Cotton Conf. (pp. 528-531). NCC.

Wilmot, C. A., \& Watson, H. (1966). Power requirements and costs for high-capacity cotton gins. Washington, DC: USDA-ERS. 


\section{APPENDIX}

Definitions of measurements used in the gin stand comparison study.

\begin{tabular}{|c|c|}
\hline Measurements & Definition \\
\hline \multicolumn{2}{|l|}{ AFIS } \\
\hline Nep size $[\mu \mathrm{m}]$ & The mean size of all neps (both fiber and seed coat neps) in the sample. \\
\hline Neps per gram & The total nep count normalized per gram. This includes both fiber and seed coat neps. \\
\hline $\mathrm{L}(\mathrm{w})[\mathrm{mm}]$ & The average length of all the fibers in the sample computed on a weight basis. \\
\hline $\mathrm{L}(\mathrm{w}) \mathrm{CV}[\%]$ & The percentage of the coefficient of variation of the length by weight. \\
\hline $\mathrm{UQL}(\mathrm{w})[\mathrm{mm}]$ & Upper Quartile Length by weight. This is the length which is exceeded by $25 \%$ of the fibers by weight. \\
\hline SFC(w) [\%] & The short fiber content ( $<0.5$ in.) of the sample (calculated by weight). \\
\hline $\mathrm{L}(\mathrm{n})[\mathrm{mm}]$ & The average length of all the fibers in the sample computed on a number basis. \\
\hline $\mathrm{L}(\mathrm{n}) \mathrm{CV}[\%]$ & The percentage of the coefficient of variation of the length by number. \\
\hline SFC(n) [\%] & The short fiber content ( $<0.5$ in.) of the sample (actual fibers counted by number). \\
\hline $\mathrm{L} 5 \%(\mathrm{n})[\mathrm{mm}]$ & Percent 1 - The length, calculated by number, that is exceeded by $5 \%$ of the fibers. \\
\hline $\mathrm{L} 2.5 \%(\mathrm{n})[\mathrm{mm}]$ & Percent 2 - The length, calculated by number, that is exceeded by $2.5 \%$ of the fibers. \\
\hline Total [count/gram] & $\begin{array}{l}\text { Total count of trash particles measured by the Trash Module; } \\
\text { this is the total of the trash and dust count per gram of the sample. }\end{array}$ \\
\hline Trash Size $[\mu \mathrm{m}]$ & The mean size of all the trash particles in the sample. \\
\hline Dust [count/gram] & The particles measured by the Trash Module that are less than 500 microns in size. \\
\hline Trash [count/gram] & All foreign matter in cotton measured by the Trash Module that is larger than 500 microns in size. \\
\hline VFM [\%] & The percentage of Visible Foreign Matter (dust and trash) in the sample. \\
\hline SCN size $[\mu \mathrm{m}]$ & The mean size of all seed coat neps in the sample. \\
\hline SCN per gram & The seed coat nep count normalized per gram. \\
\hline Fineness $[\mathrm{mTex}]$ & $\begin{array}{l}\text { The mean fiber fineness (weight per unit length) in millitex. } \\
\text { One thousand meters of fibers with a mass of } 1 \text { milligram equals } 1 \text { millitex. }\end{array}$ \\
\hline $\mathrm{IFC}[\%]$ & $\begin{array}{l}\text { Immature Fiber Content is the percentage of fibers with less than } 0.25 \text { maturity. } \\
\text { The lower the IFC\%, the more suitable the fiber is for dyeing. }\end{array}$ \\
\hline Maturity Ratio & $\begin{array}{l}\text { The ratio of fibers with a } 0.5 \text { (or more) circularity ratio divided by the amount of fibers with a } 0.25 \text { (or less) circu- } \\
\text { larity. The higher the maturity ratio, the more mature the fibers are and the better the fibers are for dyeing. }\end{array}$ \\
\hline \multicolumn{2}{|l|}{ HVI } \\
\hline Micronaire & Micronaire is a measure of fiber fineness and maturity. \\
\hline Strength & $\begin{array}{l}\text { Strength measurements are reported in terms of grams per tex. } \\
\text { A tex unit is equal to the weight in grams of } 1,000 \mathrm{~m} \text { of fiber. }\end{array}$ \\
\hline Reflectance and Yellowness & $\begin{array}{l}\text { The color of cotton is determined by the degree of reflectance }(\mathrm{Rd}) \text { and yellowness }(+\mathrm{b}) \text {. } \\
\text { Reflectance indicates how bright or dull a sample is, and yellowness indicates the degree of color pigmentation. }\end{array}$ \\
\hline Trash Area & $\begin{array}{l}\text { Trash is a measure of the amount of non-lint materials in the cotton, such as leaf and bark from the cotton plant. } \\
\text { The surface of the cotton sample is scanned by a video camera } \\
\text { and the percentage of the surface area occupied by trash particles is calculated. }\end{array}$ \\
\hline Length [mm] & $\begin{array}{l}\text { Fiber length is the average length of the longer one-half of the fibers (upper half mean length). } \\
\text { It is officially reported in } 32 \text { nds of an inch. }\end{array}$ \\
\hline Length Uniformity [\%] & The ratio between the mean length and the upper half mean length of the fibers and is expressed as a percentage. \\
\hline Shirley Visible Trash [\%] & Percent of visible trash, by weight, from the Shirley Analyzer. \\
\hline SCF (n) & The number of seed coat fragments in a $5 \mathrm{~g}$ sample of lint. \\
\hline $\mathrm{SCF}(\mathrm{w})$ & The weight of seed coat fragments in a $5 \mathrm{~g}$ sample of lint. \\
\hline Mote $(\mathrm{n})$ & The number of motes in a $5 \mathrm{~g}$ sample of lint. \\
\hline Mote (w) & The weight of motes in a $5 \mathrm{~g}$ sample of lint. \\
\hline Funiculi $(\mathrm{n})$ & The number of funiculi in a $5 \mathrm{~g}$ sample of lint. \\
\hline Funiculi (w) & The weight of funiculi in a $5 \mathrm{~g}$ sample of lint. \\
\hline Seed in the Lint $(\mathrm{n})$ & The number of cottonseed in a $5 \mathrm{~g}$ sample of lint. \\
\hline Seed in the Lint $(\mathrm{w})$ & The weight of cottonseed in a $5 \mathrm{~g}$ sample of lint. \\
\hline Linters [\%] & Measurement of the percent of lint on the cottonseed, by weight, after ginning. \\
\hline
\end{tabular}

